\title{
STUDY OF ABSENCE FROM WORK AMONG WOMEN IN A WAR FACTORY
}

BY

\section{S, WYATT}

London

\section{Nature and Scope of the Inquiry}

The investigation here described is an extension of an earlier statistical study of sickness absence among women in industry.* Both had much in common but the later study, unlike the earlier, included all the women in a factory and was concerned with absence due to leave and without permission as well as with sickness absence. The factory chosen was engaged in the manufacture of fuzes, and the absence records relate to all the women on the books during the last six months of 1943 . These consisted of 2926 women who were employed throughout the period, 332 who left, and 43 who began work during the period. The procedure adopted was to copy, from the factory records, the length and nature

TABLE 1

NUMBER OF POSSIBLE WORKING DAYS FOR WOMEN WHO REMAINED EMPLOYED (E) LEFT (L) AND BEGAN WORK (B) DURING THE PERIOD, AND DISTINGUISHING MARRIED AND SINGLE' WOMEN

\begin{tabular}{|c|c|c|c|c|c|c|}
\hline \multirow[b]{2}{*}{$\begin{array}{c}\text { Married } \\
\text { women } \\
\text { E } \\
\text { L } \\
\text { B }\end{array}$} & \multicolumn{5}{|c|}{ A-In age groups } & \multirow[b]{2}{*}{$\begin{array}{r}\text { Total } \\
187,812 \\
17,904 \\
1,260\end{array}$} \\
\hline & $\begin{array}{r}15-24 \\
52,836 \\
6,276\end{array}$ & $\begin{array}{r}25-3 \\
79,92 \\
7,04\end{array}$ & & $\begin{array}{r}35-44 \\
47,508 \\
3,012\end{array}$ & $\begin{array}{l}45+ \\
7,548 \\
1,572\end{array}$ & \\
\hline $\begin{array}{c}\text { Single } \\
\text { women } \\
\text { E } \\
\mathbf{L} \\
\text { B }\end{array}$ & $\begin{array}{r}15-24 \\
168,276 \\
2,964 \\
-\end{array}$ & $\begin{array}{r}25-3 \\
51,94 \\
1,30 \\
-\end{array}$ & & $\begin{array}{r}35+ \\
25,012 \\
960 \\
-\end{array}$ & & $\begin{array}{r}206,976 \\
\text { Total } \\
245,236 \\
5,232 \\
984\end{array}$ \\
\hline Married & & B-By & years of & f service & & 251,452 \\
\hline $\begin{array}{c}\mathbf{E} \\
\text { women } \\
\mathbf{L}\end{array}$ & $\begin{array}{c}0-1 \\
10,804 \\
1,704\end{array}$ & $\begin{array}{c}1-2 \\
35,076 \\
4,284\end{array}$ & $\begin{array}{c}2-3 \\
81,992 \\
7,320\end{array}$ & $\begin{array}{r}3-4 \\
54,168 \\
4,224\end{array}$ & $\begin{array}{l}4-5 \\
5,772 \\
372\end{array}$ & $\begin{array}{c}\text { Total } \\
187,812 \\
17,904\end{array}$ \\
\hline Single & & & & & & 205,716 \\
\hline $\begin{array}{c}\text { Women } \\
\text { L }\end{array}$ & $\begin{array}{r}19,536 \\
240\end{array}$ & $\begin{array}{r}51,948 \\
1,524\end{array}$ & $\begin{array}{r}97,384 \\
2,400\end{array}$ & $\begin{array}{r}61,124 \\
936\end{array}$ & $\begin{array}{r}15,244 \\
132\end{array}$ & $\begin{array}{r}245,236 \\
5,232 \\
250,468\end{array}$ \\
\hline
\end{tabular}

of each absence and to relate this information to factors such as civil state, age and length of service. The total number of days in the period from July 1 to December 31 was 184. The non-working days deducted from this total were: 26 Sundays, 6 days annual holiday, 2 days in September instead of August Bank holiday week-end, and 2 days at Christmas. Hence the total number of possible working days for each woman employed for the whole period was 148 .

Whilst space precludes giving the actual number of days lost from (a) sickness, (b) leave, and (c) absence without permission, the figures in Table 1 show the possible working days on which the percentage figures given later are based, and from these readers who desire to do so can calculate the actual days lost. All differences referred to have been tested for statistical significance unless otherwise stated.

\section{(a) Amount of Absence}

\section{Results obtained}

The average number of working days lost by married and single women in the last six months of 1943 through (a) sickness, $\dagger(b)$ leave, and (c) absence without permission has been expressed as a percentage of the total number of working days in the period and the figures so obtained are given in Table 2. \pm In the case of women who left or began work during the period, the percentage time lost was reckoned up to the date of leaving or from the date of entry.

Thus the time lost due to all causes was 24.9 per cent. for married women and 11.3 per cent. for single women, or an average loss of 17.5 per cent. The latter figure agrees fairly closely with the average loss of 16.8 per cent. for the same period in $\mathbf{5 2}$ factories employing a total of 168,762 , women

Approximately two-thirds of the total time lost was due to sickness absence and only a small proportion to absence without permission.

TABLE 2

PERCENTAGE OF WORKING DAYS LOST THROUGH SICKNESS, LEAVE AND ABSENCE WITHOUT PERMISSION BY WOMEN WHO REMAINED IN EMPLOYMENT (E), LEFT (L) AND BEGAN WORK (B) DURING THE PERIOD

\begin{tabular}{|c|c|c|c|c|c|c|c|c|c|c|c|}
\hline & & & & & & Mar & & & & igle & \\
\hline & & & & $\mathbf{E}$ & $\mathbf{L}$ & B & All workers & $\mathbf{E}$ & $\mathbf{L}$ & B & All workers \\
\hline Sickness $\ldots$ & . & .. & .. & $14 \cdot 5$ & 29.6 & $9 \cdot 4$ & $15 \cdot 8$ & $7 \cdot 5$ & $27 \cdot 8$ & $11 \cdot 7$ & $7 \cdot 9$ \\
\hline $\begin{array}{lll}\text { Leave } & \ldots & \ldots\end{array}$ & $\cdots$ & $\ldots$ & $\because$ & $5 \cdot 5$ & 8.4 & $4 \cdot 1$ & 5.7 & 1.5 & $4 \cdot 3$ & 3.3 & 1.5 \\
\hline Without permission & $\ddot{*}$ & $\cdots$ & $\because$ & $2 \cdot 7$ & 10.9 & 6.6 & $3 \cdot 4$ & 1.9 & 2.9 & $3 \cdot 9$ & 1.9 \\
\hline All causes $\quad \ldots$ & . & .. & . & $22 \cdot 7$ & $48 \cdot 9$ & $20 \cdot 1$ & $24 \cdot 9$ & $10 \cdot 9$ & $35 \cdot 0$ & $18 \cdot 9$ & $11 \cdot 3$ \\
\hline Number of workers & $\ddot{*}$ & $\ddot{*}$ & $\ddot{0}$ & 1,269 & 254 & 23 & 1,546 & 1,657 & 78 & 20 & 1,755 \\
\hline Per cent. of total & $\ddot{0}$ & 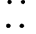 & 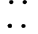 & $82 \cdot 1$ & $16 \cdot 4$ & $1 \cdot 5$ & $100 \cdot 0$ & $94 \cdot 4$ & $4 \cdot 4$ & $1 \cdot 1$ & 99.9 \\
\hline
\end{tabular}

* I.H.R.B. Rep. No. 86 (1944). H.M.S.O. Lond.

* I.H.R.B. Rep. No. 86 (1944). H.M.S.O. Lond.

$\$$ Sickness absence refers to certified sickness absence of two or more days.

Leave refers to absence with permission due mainly to husbands on leave or home duties.

Absence without permission, or casual absence, refers to occasional days lost without reasonable excuse. 
Of those who left during the period, a large majority were discharged because of ill-health or domestic difficulties, hence it is not surprising that their rate of absence before leaving was very high. It will be noted that the rate of discharge was much higher for married women than for single women; thus the former not only lost more than twice as much time as the latter but also had a much higher rate of discharge.

No significance can be attached to the absence rate of those who began work during the period because of the small number of women in this category. The inclusion of these women merely completes the picture of absence from work and their figures have no effect on the general trends.

Further analysis of the data from the main group (E) showed that the proportion of married women who were absent for more than half the period was $5 \cdot 3$ per cent. and of single women 1.5 per cent. and they accounted for 16.5 per cent. and 10.0 per cent. respectively of the total time lost by these two groups. Hence comparatively few women were responsible for a fairly large proportion of the total time lost.

\section{(b) Absence in relation to Age}

The amount of absence recorded for married and single women in different age groups is shown in Table $3 .^{*}$

Before considering the amount of absence, it may be noted that 68.2 per cent. of the single women were under 25 and only 10.5 per cent. over 35 ; the corresponding figures for married women were $29 \cdot 0$ and $28 \cdot 6$ per cent. respectively.

There was a difference between the age distributions of married women in the $E$ and $L$ groups, the proportion of leavers over 35 being relatively high. Since there was no significant difference between the corresponding groups of single women, it follows that the age distribution of leavers was related to civil state.

There was also a difference in the age distributions of married and single women in the $\mathrm{E}$ groups owing to the predominance of single women under 25 , hence the age distribution of all married and single women was different.

As regards sickness absence, the figures of both married and single women tended, with the exception of one age group, to increase as age increased. The exception was the relatively high rate of absence of married women under 25 which was most noticeable in the main group (E). A similar tendency was also noticeable in the group of single women who left during the period.
Absence due to leave was, for married women, also most marked in the lowest age group but, unlike sickness absence, it continued to decrease as age increased. The corresponding figures for single women showed no significant difference.

Absence without permission tended, if anything, to decrease as age increased, the only exception worth noting being the rise in the small group of married women over 45 who left before the end of the period.

Although the figures in Table 3 show that the age of workers must be taken into account when considering absence from work, of more importance is the demonstration that, age for age, married women lost more time than single women. In other words, the higher rate of absence of married women (Table 2) was not due to their higher average age but must be attributed to the effects of the additional duties and difficulties of married life. It is also significant that the difference between the amount of absence of married and single women decreased as age increased. The ratios for different age groups were:

$\begin{array}{ccc}\text { Age group } & \text { Married } & \text { Ratio } \\ 15-24 & 2.49 & \text { Single } \\ 25-34 & 2.06 & 1.00 \\ 35+ & 1.85 & 1.00 \\ & & 1.00\end{array}$

These figures suggest that the additional strains of married life decreased with increasing age though it is also possible that the worries and difficulties of some single women increased with age.

The figures in Table 3 also show that the rate of discharge of married and single women varied in the different age groups. The percentage rate $\dagger$ for each age group was:

\begin{tabular}{cccc}
\multicolumn{2}{c}{ Married } & \multicolumn{2}{c}{ Single } \\
Age & Percentage & Age & $\begin{array}{c}\text { Percentage } \\
\text { group }\end{array}$ \\
rate & group & rate \\
$15-24$ & $19 \cdot 0$ & $15-24$ & $3 \cdot 9$ \\
$25-34$ & $16 \cdot 1$ & $25-34$ & $4 \cdot 6$ \\
$35-44$ & $11 \cdot 7$ & $35+$ & $7 \cdot 5$ \\
$45+$ & $26 \cdot 2$ & &
\end{tabular}

Thus the rate of discharge of married women decreased up to the age group 35-44 and then increased, while that of single women continued to increase in each higher age group. There was no apparent reason, apart from the effects of married life, why the rate of discharge of

TABLE 3

PERCENTAGE OF WORKING DAYS LOST THROUGH SICKNESS, LEAVE AND ABSENCE WITHOUT PERMISSION BY WOMEN IN DIFFERENT AGE GROUPS WHO REMAINED IN EMPLOYMENT (E) AND
LEFT (L) DURING THE PERIOD

\begin{tabular}{|c|c|c|c|c|c|c|c|c|c|c|c|c|}
\hline & & & \multicolumn{6}{|c|}{$\begin{array}{l}\text { Married women } \\
\text { Age group }\end{array}$} & \multicolumn{4}{|c|}{$\begin{array}{l}\text { Single women } \\
\text { Age group }\end{array}$} \\
\hline & & & Group & $15-24$ & $25-34$ & $35-44$ & $45+$ & All ages & $15-24$ & $25-34$ & $35+$ & All ages \\
\hline Sickness & . & . & $\begin{array}{c}\text { E } \\
\text { Loth }\end{array}$ & $\begin{array}{l}15 \cdot 4 \\
29 \cdot 8 \\
16 \cdot 9\end{array}$ & $\begin{array}{l}13 \cdot 9 \\
28 \cdot 8 \\
15 \cdot 1\end{array}$ & $\begin{array}{l}14 \cdot 5 \\
29 \cdot 1 \\
15 \cdot 4\end{array}$ & $\begin{array}{l}15 \cdot 1 \\
33 \cdot 3 \\
18 \cdot 3\end{array}$ & $\begin{array}{l}14 \cdot 5 \\
29 \cdot 6 \\
15 \cdot 8\end{array}$ & $\begin{array}{r}7 \cdot 2 \\
27 \cdot 0 \\
7 \cdot 5\end{array}$ & $\begin{array}{r}8 \cdot 1 \\
21 \cdot 1 \\
8 \cdot 4\end{array}$ & $\begin{array}{r}8 \cdot 5 \\
39 \cdot 5 \\
9 \cdot 6\end{array}$ & $\begin{array}{r}7 \cdot 5 \\
27 \cdot 8 \\
7 \cdot 9\end{array}$ \\
\hline Leave & $\cdots$ & . & $\underset{\text { Both }}{\text { E }}$ & $\begin{array}{l}6 \cdot 1 \\
9 \cdot 8 \\
6 \cdot 5\end{array}$ & $\begin{array}{l}5 \cdot 7 \\
8 \cdot 6 \\
5 \cdot 9\end{array}$ & $\begin{array}{l}5 \cdot 0 \\
6 \cdot 2 \\
5 \cdot 0\end{array}$ & $\begin{array}{l}2 \cdot 0 \\
6 \cdot 4 \\
2 \cdot 8\end{array}$ & $\begin{array}{l}5 \cdot 5 \\
8 \cdot 4 \\
5 \cdot 7\end{array}$ & $\begin{array}{l}1 \cdot 3 \\
5 \cdot 2 \\
1 \cdot 4\end{array}$ & $\begin{array}{l}1 \cdot 7 \\
1 \cdot 8 \\
1 \cdot 7\end{array}$ & $\begin{array}{l}1 \cdot 8 \\
4 \cdot 6 \\
1.9\end{array}$ & $\begin{array}{l}1 \cdot 5 \\
4 \cdot 3 \\
1 \cdot 5\end{array}$ \\
\hline Without $p$ & ermission & . & $\begin{array}{c}\text { E } \\
\text { L } \\
\text { Both }\end{array}$ & $\begin{array}{r}2.9 \\
10 \cdot 0 \\
3 \cdot 7\end{array}$ & $\begin{array}{r}2 \cdot 7 \\
11 \cdot 4 \\
3 \cdot 4\end{array}$ & $\begin{array}{l}2 \cdot 5 \\
7 \cdot 1 \\
2 \cdot 8\end{array}$ & $\begin{array}{r}1 \cdot 9 \\
19 \cdot 3 \\
4.9\end{array}$ & $\begin{array}{r}2 \cdot 7 \\
10 \cdot 9 \\
3 \cdot 4\end{array}$ & $\begin{array}{l}2 \cdot 0 \\
2 \cdot 8 \\
2 \cdot 0\end{array}$ & $\begin{array}{l}1 \cdot 8 \\
3 \cdot 5 \\
1 \cdot 8\end{array}$ & $\begin{array}{l}1 \cdot 3 \\
2 \cdot 2 \\
1 \cdot 3\end{array}$ & $\begin{array}{l}1.9 \\
2.9 \\
1.9\end{array}$ \\
\hline All causes & $\ldots$ & . & $\underset{\text { Both }}{\mathrm{E}}$ & $\begin{array}{l}24 \cdot 4 \\
49 \cdot 6 \\
27 \cdot 1\end{array}$ & $\begin{array}{l}22 \cdot 3 \\
48 \cdot 8 \\
24 \cdot 4\end{array}$ & $\begin{array}{l}22 \cdot 0 \\
42 \cdot 4 \\
23 \cdot 2\end{array}$ & $\begin{array}{l}19 \cdot 0 \\
59 \cdot 0 \\
26 \cdot 0\end{array}$ & $\begin{array}{l}22 \cdot 7 \\
48 \cdot 9 \\
24 \cdot 9\end{array}$ & $\begin{array}{l}10 \cdot 5 \\
35 \cdot 0 \\
10 \cdot 9\end{array}$ & $\begin{array}{l}11 \cdot 6 \\
26 \cdot 4 \\
11 \cdot 9\end{array}$ & $\begin{array}{l}11 \cdot 6 \\
46 \cdot 3 \\
12 \cdot 8\end{array}$ & $\begin{array}{l}10 \cdot 9 \\
35 \cdot 0 \\
11 \cdot 3\end{array}$ \\
\hline $\begin{array}{l}\text { Number o } \\
\text { Per cent. }\end{array}$ & $\begin{array}{l}\text { f workers } \\
\text { of total . }\end{array}$ & $\begin{array}{l}\cdots \\
\ldots\end{array}$ & $\begin{array}{c}\text { E } \\
\text { L } \\
\text { Both }\end{array}$ & $\begin{array}{c}357 \\
85 \\
442 \\
29 \cdot 0\end{array}$ & $\begin{array}{l}540 \\
105 \\
645 \\
42 \cdot 4\end{array}$ & $\begin{array}{c}321 \\
43 \\
364 \\
23 \cdot 9\end{array}$ & $\begin{array}{l}51 \\
21 \\
72 \\
4 \cdot 7\end{array}$ & $\begin{array}{r}1,269 \\
254 \\
1,523 \\
100 \cdot 0\end{array}$ & $\begin{array}{r}1,137 \\
47 \\
1,184 \\
68 \cdot 2\end{array}$ & $\begin{array}{c}351 \\
17 \\
368 \\
21 \cdot 2\end{array}$ & $\begin{array}{c}169 \\
14 \\
183 \\
10 \cdot 5\end{array}$ & $\begin{array}{r}1,657 \\
78 \\
1,735 \\
99.9\end{array}$ \\
\hline
\end{tabular}

* The few women who began work during the period (23 married women and 20 single women) have not been included as their absence

$t$ Based on the total number on the books during the period, i.e. including the few women who began work during the period. 
young married women should be so much higher than that of single women of the same age, and the figures thus emphasize still more the burdens of younger married women. At the same time there is reason to believe that some of the younger women resented continued employment in the factory, either because of personal reasons or because they were 'directed,' and took advantage of -every possible excuse to leave. It is probable, for instance, that some young women decided to start a family so as to obtain release from factory work.

It may be noted that the exclusion of absences due to pregnancy from the figures of sickness absence in Table 3 tended, if anything, to accentuate the relation between sickness absence and age, viz.:

\begin{tabular}{|c|c|c|c|c|c|c|}
\hline \multirow{2}{*}{ Group } & & & \multicolumn{4}{|c|}{ Age groups (married women) } \\
\hline & & & $15-24$ & $25-34$ & $35-44$ & \\
\hline & & . & $13 \cdot 2$ & $11 \cdot 4$ & $14 \cdot 2$ & \\
\hline & .. & . & $23 \cdot \overline{2}$ & $22 \cdot 1$ & 27.6 & \\
\hline Both & .. & .. & $14 \cdot 2$ & $12 \cdot 3$ & $15 \cdot 0$ & 18 \\
\hline
\end{tabular}

Finally, it should be mentioned that the relation between absence and age as shown in Table 3 was not affected by length of service since there were no important differences in the length of service distributions of women in the different age groups.

\section{(c) Absence in relation to Length of Service}

A classification of absence according to length of service is given in Table 4 . $^{*}$ The length of service was reckoned up to the end of June, 1943.

\section{TABLE 4}

\section{PERCENTAGE OF WORKING DAYS LOST THROUGH SICKNESS, LEAVE AND ABSENCE WITHOUT SICKNESS, LEAVE AND ABSENCE WITHOUT LENGTHS OF SERVICE WHO REMAINED IN EMPLOYMENT (E) AND LEFT (L) DURING THE PERIOD}

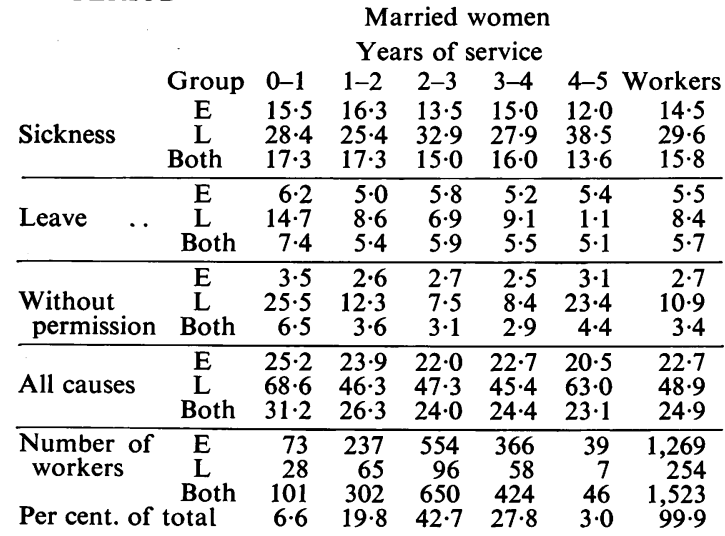

\begin{tabular}{|c|c|c|c|c|c|c|c|}
\hline \multirow[b]{2}{*}{ Sickness } & \multicolumn{7}{|c|}{ Single women } \\
\hline & $\begin{array}{c}\mathrm{E} \\
\text { Loth }\end{array}$ & $\begin{array}{r}7.9 \\
16.7 \\
8.0\end{array}$ & $\begin{array}{r}8 \cdot 3 \\
26 \cdot 2 \\
8 \cdot 8\end{array}$ & $\begin{array}{r}7.0 \\
30.2 \\
7.6\end{array}$ & $\begin{array}{r}7.9 \\
30 \cdot 8 \\
8.3\end{array}$ & $\begin{array}{l}5.6 \\
2.3 \\
5.6\end{array}$ & $\begin{array}{r}7.5 \\
27.8 \\
7.9\end{array}$ \\
\hline Leave & $\begin{array}{c}\text { E } \\
\text { L } \\
\text { Both }\end{array}$ & $\begin{array}{l}1 \cdot 1 \\
0.8 \\
1.1\end{array}$ & $\begin{array}{l}1.7 \\
6.7 \\
1.9\end{array}$ & $\begin{array}{l}1.4 \\
1.6 \\
1.4\end{array}$ & $\begin{array}{l}1.7 \\
8.4 \\
1.8\end{array}$ & $\begin{array}{l}0.9 \\
1.5 \\
0.9\end{array}$ & $\begin{array}{l}1.5 \\
4^{\prime \prime} 3 \\
1.5\end{array}$ \\
\hline $\begin{array}{l}\text { Without } \\
\text { permission }\end{array}$ & $\begin{array}{c}\text { E } \\
\mathbf{L} \\
\text { Both }\end{array}$ & $\begin{array}{l}1 \cdot 7 \\
4.0 \\
1.7\end{array}$ & $\begin{array}{l}1.9 \\
1.9 \\
1.9\end{array}$ & $\begin{array}{l}1.9 \\
3.7 \\
1.9\end{array}$ & $\begin{array}{l}2.0 \\
1.5 \\
2.0\end{array}$ & $\begin{array}{l}2 \cdot 0 \\
6 \cdot 8 \\
2 \cdot 1\end{array}$ & $\begin{array}{l}1.9 \\
2.9 \\
1.9\end{array}$ \\
\hline All causes & $\begin{array}{c}\text { E } \\
\text { Loth }\end{array}$ & $\begin{array}{l}10 \cdot 7 \\
21.5 \\
10.8\end{array}$ & $\begin{array}{l}11.9 \\
34.8 \\
12.6\end{array}$ & $\begin{array}{l}10.3 \\
35.5 \\
10.9\end{array}$ & $\begin{array}{l}11 \cdot 6 \\
40 \cdot 7 \\
12 \cdot 1\end{array}$ & $\begin{array}{r}8.5 \\
10.6 \\
8.6\end{array}$ & $\begin{array}{l}10.9 \\
35.0 \\
11.3\end{array}$ \\
\hline $\begin{array}{l}\text { Number of } \\
\text { workers } \\
\text { Per cent. of }\end{array}$ & $\begin{array}{c}\text { E } \\
\text { L } \\
\text { Both } \\
\text { total }\end{array}$ & $\begin{array}{r}132 \\
4 \\
136 \\
7.8\end{array}$ & $\begin{array}{r}351 \\
27 \\
378 \\
21.8\end{array}$ & $\begin{array}{r}658 \\
32 \\
690 \\
39 \cdot 8\end{array}$ & $\begin{array}{r}413 \\
12 \\
425 \\
24 \cdot 5\end{array}$ & $\begin{array}{r}103 \\
3 \\
106 \\
6 \cdot 1\end{array}$ & $\begin{array}{r}1,657 \\
78 \\
1,735 \\
100 \cdot 0\end{array}$ \\
\hline
\end{tabular}

* As in Table 3 , the few women who began work during the period
Thus approximately $70 \cdot 0$ per cent. of the women had less than three years of service and very few had been employed for more than four years.

As regards absence from work, there was no consistent relation between the amount of time lost and length of service. Married women with less than two years of service tended to lose more time than those employed for longer periods, but the trend for single women was irregular.

Women with more than three years of service entered the factory at a time when it was possible to choose the fittest from a plentiful supply of labour. According to the management, they were 'handpicked' from the standpoint of health, appearance and suitability for work. Those with two to three years of service were also chosen with care but the standard was rather lower because of the more restricted choice. The shorter service workers were engaged when the demand for labour was almost equal to the supply and there was practically no choice. This progressive lowering of the standard would, other things being equal, tend to cause an increase in absence as length of service decreased. A similar effect would be produced by the weeding out of those most prone to absence, since the labour wastage due to this cause might be expected to decrease in each successive year of employment. This view is supported by the following figures which show the percentage discharged in each length of service group during the last six months of 1943 .

\section{Married women Single women} Years of $\begin{gathered}\text { Number } \\ \text { service } \\ \text { discharged discharged discharged }\end{gathered}$ discharged
dischanger

$\begin{array}{rrrrr}0-1 & 28 & 27 \cdot 7 & 4 & 2 \cdot 9 \\ 1-2 & 65 & 21 \cdot 5 & 27 & 7 \cdot 1 \\ 2-3 & 96 & 14 \cdot 8 & 32 & 4 \cdot 6 \\ 3-4 & 58 & 13 \cdot 7 & 12 & 2 \cdot 8 \\ 4-5 & 7 & 15 \cdot 2 & 3 & 2 \cdot 8\end{array}$

The preceding considerations would probably account for the comparatively good records of those who entered the factory before the outbreak of war.

\section{(d) Sickness Absence}

The figures in Table 2 show that approximately twothirds of the total time lost was due to sickness absence hence a more detailed analysis of this source of loss is desirable. The procedure adopted for this purpose follows the lines recommended by a recent report on the recording of sickness absence in industry, $\dagger$ and the results are given in Table 5. They refer to women who remained in employment throughout the period (group E) and to those who left during the period (group L).

TABLE 5

\section{SICKNESS ABSENCE CLASSIFIED ACCORDING TO} DISEASE GROUPS

(Average number of days lost in each group expressed as a percentage of the number of working days possible)

$$
\text { Group E Group L }
$$

Disease group Married Single Married Single

I. Colds and in-

$\begin{array}{llllll}\text { fluenza } & \cdots & 2.99 & 1.91 & 2.62 & 1.97\end{array}$

II. Respiratory $\begin{array}{lllllll}\text { system } & \ldots & 1.08 & 0.54 & 1.19 & 1.97\end{array}$

III. Digestive $\begin{array}{llllll}\text { system } & \ldots & 1.64 & 1.36 & 5.07 & 2.96\end{array}$

IV. Rheumatism $\begin{array}{llllll}\text { group } & \ldots & 0.93 & 0.27 & 0.93 & 1.80\end{array}$

V. Functional

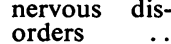

VI. Accidents at Alace of work 0.22

VII. Unclassified \begin{tabular}{lllll} 
conditions $\ldots$ & 7.31 & 3.05 & 17.85 & 15.43 \\
\hline
\end{tabular} $\begin{array}{lllll}\text { All groups } \ldots & 14.52 & 7.52 & 29.61 & 27.80\end{array}$

† I.H.R.B. Rep. No. 85 (1944). H.M.S.O. Lond. 
Considering first the main group $(E)$, the figures show that colds and influenza were the most important single cause of sickness absence. The figures in question were, however, inflated by the effects of a mild influenza epidemic towards the end of 1943 and were almost three times as large as those for the corresponding period in 1942. Diseases of the digestive system were also responsible for much sickness absence and, among married women, the respiratory and rheumatism groups were prominent. It will be noted that functional nervous disorders occupied a relatively low position in the list of causes.

In the group of leavers (L), the figures show that married women had less absence through colds and influenza but more absence through digestive ailments and functional nervous disorders than those in the main group (E). Single women who left had more absence due to digestive ailments, rheumatism and functional nervous disorders. Both married and single women had more absence through unclassified causes.

Since the unclassified diseases accounted for approximately one-half of the total time lost through sickness, a further analysis was made with the following results:

Group E Group L

Disease group Married Single Married Single

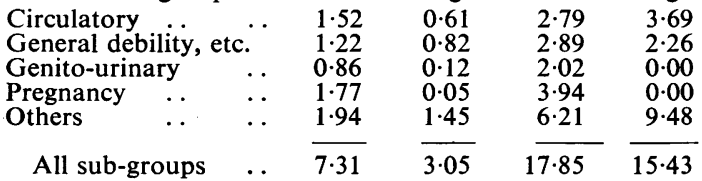

This classification shows that diseases of the circulatory system and ailments diagnosed as general debility, asthenia or general fatigue were also important causes of sickness absence. Among married women, the time lost through pregnancy and its complications was relatively high.

The figures in general indicate the types of sickness absence amongst those who left during the period. In a large majority of cases these absences were the main causes of their dismissal. Approximately 90 per cent. of the sickness absence of married leavers and 80 per cent. of single leavers were incurred by women who were discharged wholly or partly on grounds of ill-health. The remainder were usually discharged or allowed to leave because of domestic difficulties or removal to another district.

The relation between age and sickness absence in the main disease groups is shown in Table 6.
The figures show that the relation between sickness absence and age varied in the different disease groups. In some groups, the time lost increased with age but in others the opposite tendency was noticeable. In the main group (E) the figures show that the increase in sickness absence among married women under 25 (Table 3) was due mainly to colds and influenza, diseases of the circulatory system and general debility. Absences due to digestive ailments and pregnancy were also very prominent in this age group but they were also equally noticeable in the next age group (25-34). On the other hand, the absence rate for the circulatory and respiratory groups was highest among those over 45 .

The figures for single women in the colds and influenza and rheumatism groups tended to increase with age and in this respect they were similar to the general trend of sickness absence as a whole (Table 3 ). They tended to decrease with age in the circulatory group but in the remainder the trends were irregular.

The figures for those who left during the period (group L) show that the relation between age and absence in the various disease groups was often substantially different from the relation in the main group (E). The married women who left, as compared with those who remained in employment, had in several disease groups a higher rate of absence in the lower and higher age groups. These increases were particularly noticeable in the colds and influenza group (over 35); the respiratory group (under 25); the digestive group (under 35); the rheumatism group (over 45); the circulatory and general debility groups (25-45), and pregnancy (under 25). The figures for single women who left are less reliable because of the smaller number of women in each age group. The most noticeable differences between these women and those in the main group (E) were a relatively higher rate of absence among the older women (over 35) in the colds and influenza, digestive, rheumatism and circulatory groups and a lower rate in the respiratory and general debility groups.

The figures in general give some indication of the relative importance of the diseases which preceded discharge from work and the age groups in which these diseases were most prevalent.

An analysis was also made of the relation between length of service and sickness absence in the main disease groups. Since it has been shown that the relation between sickness absence and age varied in the different disease groups and because, from general experience, one expects age to be related to length of service, it was evident that to compare crude percentages (total days lost/total days possible) would be fallacious. For example, it has been shown (Table 6) that among

TABLE 6

TYPE OF SICKNESS AND AGE

(Number of days lost expressed as a percentage of the number of working days possible)

\begin{tabular}{|c|c|c|c|c|c|c|c|c|c|}
\hline \multirow[b]{3}{*}{ Disease group } & & \multirow[b]{3}{*}{ Group } & \multicolumn{7}{|c|}{ Age groups } \\
\hline & & & \multicolumn{4}{|c|}{ Married women } & \multicolumn{3}{|c|}{ Single women } \\
\hline & & & $15-24$ & $25-34$ & $35-44$ & $45+$ & $15-24$ & $25-34$ & $35+$ \\
\hline Colds and influenza & . & $\begin{array}{l}\mathrm{E} \\
\mathrm{L}\end{array}$ & $\begin{array}{c}3.48 \\
1.26\end{array}$ & $\begin{array}{l}2 \cdot 55 \\
2 \cdot 16\end{array}$ & $\begin{array}{l}3 \cdot 17 \\
5 \cdot 34\end{array}$ & $\begin{array}{l}3 \cdot 15 \\
4 \cdot 90\end{array}$ & $\begin{array}{l}1.72 \\
1.32\end{array}$ & $\begin{array}{l}2 \cdot 27 \\
2 \cdot 29\end{array}$ & $\begin{array}{l}2.46 \\
3.54\end{array}$ \\
\hline Respiratory system & . & $\begin{array}{l}\mathrm{E} \\
\mathrm{L}\end{array}$ & $\begin{array}{l}0.81 \\
1.67\end{array}$ & $\begin{array}{l}1.09 \\
0.58\end{array}$ & $\begin{array}{l}1 \cdot 30 \\
1.09\end{array}$ & $\begin{array}{l}1 \cdot 58 \\
2 \cdot 16\end{array}$ & $\begin{array}{l}0 \cdot 54 \\
2 \cdot 19\end{array}$ & $\begin{array}{l}0.62 \\
2.90\end{array}$ & $\begin{array}{l}0 \cdot 38 \\
0.00\end{array}$ \\
\hline Digestive system & . & $\begin{array}{l}\mathrm{E} \\
\mathrm{L}\end{array}$ & $\begin{array}{l}1.85 \\
6.52\end{array}$ & $\begin{array}{l}1 \cdot 86 \\
6 \cdot 60\end{array}$ & $\begin{array}{l}1.24 \\
1.09\end{array}$ & $\begin{array}{l}0.36 \\
0.00\end{array}$ & $\begin{array}{l}1.30 \\
0.84\end{array}$ & $\begin{array}{l}1 \cdot 61 \\
3 \cdot 13\end{array}$ & $\begin{array}{l}1.27 \\
9 \cdot 27\end{array}$ \\
\hline Rheumatism group & . & $\begin{array}{l}\mathrm{E} \\
\mathrm{L}\end{array}$ & $\begin{array}{l}0.40 \\
0.53\end{array}$ & $\begin{array}{l}0.73 \\
0.24\end{array}$ & $\begin{array}{l}1.72 \\
0.70\end{array}$ & $\begin{array}{l}1.95 \\
6.11\end{array}$ & $\begin{array}{l}0.23 \\
0.27\end{array}$ & $\begin{array}{l}0.31 \\
0.00\end{array}$ & $\begin{array}{l}0.42 \\
8.96\end{array}$ \\
\hline Circulatory system & $\cdots$ & $\begin{array}{l}\mathbf{E} \\
\mathbf{L}\end{array}$ & $\begin{array}{l}1.93 \\
1.72\end{array}$ & $\begin{array}{l}0.89 \\
2.63\end{array}$ & $\begin{array}{l}1.77 \\
5.88\end{array}$ & $\begin{array}{l}3.92 \\
1.91\end{array}$ & $\begin{array}{l}0.68 \\
5 \cdot 30\end{array}$ & $\begin{array}{l}0.56 \\
0.00\end{array}$ & $\begin{array}{l}0.21 \\
3.75\end{array}$ \\
\hline General debility & .. & $\begin{array}{l}\mathbf{E} \\
\mathbf{L}\end{array}$ & $\begin{array}{l}1.61 \\
2.39\end{array}$ & $\begin{array}{l}1 \cdot 16 \\
3.62\end{array}$ & $\begin{array}{l}0.90 \\
3.55\end{array}$ & $\begin{array}{l}1.03 \\
0.32\end{array}$ & $\begin{array}{l}0.85 \\
3.54\end{array}$ & $\begin{array}{l}0.75 \\
0.99\end{array}$ & $\begin{array}{l}0.79 \\
0.00\end{array}$ \\
\hline Pregnancy .. & $\cdots$ & $\begin{array}{l}\mathbf{E} \\
\mathbf{L}\end{array}$ & $\begin{array}{l}2 \cdot 25 \\
6.87\end{array}$ & $\begin{array}{l}2.47 \\
3.88\end{array}$ & $\begin{array}{l}0.35 \\
0.00\end{array}$ & $\begin{array}{l}0.00 \\
0.00\end{array}$ & 二 & 二 & 二 \\
\hline
\end{tabular}


married women (E) the sickness absence from colds and influenza was at its peak at ages under 25 . If, therefore, the group with 4 to 5 years of service included a high proportion of women under 25 , this of itself would tend towards a high rate of absence from colds and influenza in this length of service group. Since, however, the tabulation of sickness rates for each length of service group, both by disease and age, was precluded by space, it was decided to use standardized rates, allowing for differences in the age distributions of the four occupation types, calculated in the same manner as the standardized death-rates used by the Registrar-General in mortality statistics.

Taking the number of possible working days (in age groups) for married (E) and single (E) combined, as our standard, the rates in Table 7 are those which would prevail for each disease and occupation group if, whilst retaining its own rate of ages, it had instead of its real population, one whose total possible working days were as in the standard adopted. By this method valid comparability of the rates in the table is assured.

These figures refute any expectation that absence due to certain types of sickness might increase with length of service. The figures for the main group (E) show, if anything, the opposite tendency, especially in the colds and influenza group (married women) and in the respiratory group (single women). In most disease groups the workers with longest service, especially married women, had the least sickness absence.

The absence figures of those who left (group L) were more variable and less reliable because of the small number of women in most length of service groups. Apart from the relatively high rate of absence of the few married women with long service in the digestive, rheumatism and circulatory groups, the women with one to four years of service usually had the most absence.

In general, the tendencies shown by these figures support the view already expressed that any increase in sickness absence due to continued employment under war-time conditions is likely to be counteracted by the progressive weeding-out of those most prone to absence. If, therefore, sickness absence were found to increase with length of employment, the results would be highly significant.

\section{Comments on Results}

The women employed in this factory were absent from work for, on the average, approximately one working day per week. This high rate of loss was due mainly to the employment of older women and married women with their home duties, to a lowering of the physical standards of those accepted for employment, and to the stresses and strains induced by four years of war. It was also attributable in part to the specific ailments and physical disabilities of women as well as to increased susceptibility to fatigue and emotional strain.

Married women lost an average of one working week in every four but single women lost less than half this amount. This difference was not due to the higher average age of married women since, in each age group, married women lost much more time than single women and the increase was least among women over 35 . It was due to the additional burdens and difficulties of married life which, judging by the results, were most severe among young married women. The high rate of absence of married women noted in this and in other investigations suggests that they have been too extensively employed in industry, and it is probable that the health of some of the younger women may have been seriously undermined by the dual task of running a home and doing factory work. A substantial portion of the total time lost was due to the frequent or prolonged absence of comparatively few women (see p. 87) and there is little doubt that most of these were unfit for fulltime factory work.

The results also illustrate some of the uses of absence records providing they are accurately compiled and interpreted with care. Most factories now keep separate records for men and women, but it may also be necessary to distinguish between the absence rates of married and single women, or at least to indicate the proportions employed. Thus, taking the absence rates of married and single women as 25 per cent. and 10 per cent. respectively, the average or crude loss in a factory employing 1000 married women and 2000 single women would be 15 per cent. If, however, the proportions were reversed, the average loss would be 20 per cent. Hence, unless married and single women are employed in approximately the same proportions in different groups or factories, comparisons of absence rates may be misleading.

A somewhat similar error of interpretation may arise as the result of age differences. Thus, in the present inquiry, 263 married women were formerly employed as weavers and 218 were engaged on other factory work. Their absence rates were $20 \cdot 8$ per cent. and $25 \cdot 3$ per cent.

TYPE OF SICKNESS ABSENCE AND LENGTH OF SERVICE

(Number of days lost expressed as a percentage of the number of working days possible, but adjusted to allow for differences in the age constitution of the four types of worker)

\begin{tabular}{|c|c|c|c|c|c|c|c|c|c|c|c|}
\hline \multirow[b]{3}{*}{ Disease group } & \multirow[b]{3}{*}{ Group } & \multirow{2}{*}{\multicolumn{7}{|c|}{ Married women $\quad$ Years of service }} & \multirow{2}{*}{\multicolumn{3}{|c|}{ Single women }} \\
\hline & & & & & & & & & & & \\
\hline & & $0-1$ & $1-2$ & $2-3$ & $3-4$ & $4-5$ & $0-1$ & $1-2$ & $2-3$ & $3-4$ & $4-5$ \\
\hline Colds and influenza & $\underset{\mathrm{L}}{\mathrm{E}}$ & $\begin{array}{l}3.92 \\
1.98\end{array}$ & $\begin{array}{l}3 \cdot 54 \\
1 \cdot 69\end{array}$ & $\begin{array}{l}3 \cdot 33 \\
1.94\end{array}$ & $\begin{array}{l}2 \cdot 46 \\
3 \cdot 30\end{array}$ & $\begin{array}{l}2.75 \\
0.00\end{array}$ & $\begin{array}{l}1 \cdot 70 \\
0.00\end{array}$ & $\begin{array}{l}2 \cdot 21 \\
1 \cdot 79\end{array}$ & $\begin{array}{l}1 \cdot 88 \\
2 \cdot 04\end{array}$ & $\begin{array}{r}2 \cdot 25 \\
17 \cdot 96\end{array}$ & $\begin{array}{l}1.75 \\
0.00\end{array}$ \\
\hline Respiratory system & $\underset{\mathrm{L}}{\mathrm{E}}$ & $\begin{array}{l}0.94 \\
0.09\end{array}$ & $\begin{array}{l}1 \cdot 49 \\
1 \cdot 43\end{array}$ & $\begin{array}{l}0 \cdot 74 \\
1 \cdot 28\end{array}$ & $\begin{array}{l}1 \cdot 13 \\
2 \cdot 00\end{array}$ & $\begin{array}{l}0 \cdot 37 \\
0 \cdot 00\end{array}$ & $\begin{array}{l}1 \cdot 12 \\
0 \cdot 00\end{array}$ & $\begin{array}{l}0 \cdot 59 \\
1 \cdot 81\end{array}$ & $\begin{array}{l}0 \cdot 53 \\
3 \cdot 62\end{array}$ & $\begin{array}{l}0.39 \\
0.00\end{array}$ & $\begin{array}{l}0 \cdot 28 \\
0 \cdot 00\end{array}$ \\
\hline Digestive system & $\begin{array}{l}\mathrm{E} \\
\mathrm{L}\end{array}$ & $\begin{array}{l}1 \cdot 74 \\
2 \cdot 82\end{array}$ & $\begin{array}{l}1 \cdot 46 \\
4 \cdot 13\end{array}$ & $\begin{array}{l}1 \cdot 58 \\
.3 \cdot 23\end{array}$ & $\begin{array}{l}2 \cdot 42 \\
7 \cdot 25\end{array}$ & $\begin{array}{r}0 \cdot 36 \\
13 \cdot 32\end{array}$ & $\begin{array}{l}1 \cdot 67 \\
2 \cdot 10\end{array}$ & $\begin{array}{l}1.20 \\
1.62\end{array}$ & $\begin{array}{l}1 \cdot 37 \\
5 \cdot 55\end{array}$ & $\begin{array}{r}1.57 \\
5.26\end{array}$ & $\begin{array}{l}0.85 \\
0.00\end{array}$ \\
\hline Rheumatism group & $\begin{array}{l}E \\
L\end{array}$ & $\begin{array}{l}0.44 \\
0.00\end{array}$ & $\begin{array}{l}0.75 \\
0.72\end{array}$ & $\begin{array}{l}0.94 \\
0.53\end{array}$ & $\begin{array}{l}0.53 \\
0.51\end{array}$ & $\begin{array}{l}0 \cdot 17 \\
6 \cdot 11\end{array}$ & $\begin{array}{l}0.08 \\
0.00\end{array}$ & $\begin{array}{l}0.34 \\
0.00\end{array}$ & $\begin{array}{l}0 \cdot 27 \\
4 \cdot 33\end{array}$ & $\begin{array}{l}0.30 \\
0.00\end{array}$ & $\begin{array}{l}0.23 \\
0.00\end{array}$ \\
\hline Circulatory group & $\begin{array}{l}\mathrm{E} \\
\mathrm{L}\end{array}$ & $\begin{array}{l}2 \cdot 36 \\
2 \cdot 33\end{array}$ & $\begin{array}{l}1.73 \\
2 \cdot 36\end{array}$ & $\begin{array}{l}1.44 \\
3.80\end{array}$ & $\begin{array}{l}1.98 \\
0.00\end{array}$ & $\begin{array}{l}0.43 \\
9.67\end{array}$ & $\begin{array}{l}0 \cdot 70 \\
2 \cdot 81\end{array}$ & $\begin{array}{l}0.55 \\
8 \cdot 14\end{array}$ & $\begin{array}{l}0.62 \\
2.85\end{array}$ & $\begin{array}{l}0.40 \\
0.00\end{array}$ & $\begin{array}{l}0.53 \\
1.28\end{array}$ \\
\hline General debility & $\begin{array}{l}E \\
L\end{array}$ & $\begin{array}{l}1.94 \\
3.41\end{array}$ & $\begin{array}{l}1 \cdot 90 \\
2 \cdot 23\end{array}$ & $\begin{array}{l}1 \cdot 18 \\
2 \cdot 49\end{array}$ & $\begin{array}{l}1 \cdot 24 \\
3 \cdot 54\end{array}$ & $\begin{array}{l}0.88 \\
1.30\end{array}$ & $\begin{array}{l}0.92 \\
0.00\end{array}$ & $\begin{array}{l}0.67 \\
3.72\end{array}$ & $\begin{array}{l}0.67 \\
2.47\end{array}$ & $\begin{array}{l}1.20 \\
1.00\end{array}$ & $\begin{array}{l}0.22 \\
0.00\end{array}$ \\
\hline
\end{tabular}


respectively and it might be inferred that the former were more suitable than the latter for work in munition factories. The ex-weavers, however, as compared with the former factory workers, included a smaller proportion of younger women and a larger proportion of older women. Since younger married women had more absence than older women (Table 3), this would doubtless account for the higher absence rate of women previously employed on factory work. Similar age differences may exist among women in different factories and give rise to similar results.

This inquiry emphasizes the importance of studying the new employee from the standpoint of fitness for work; it also indicates the need for periodic examination of those accepted for employment. This procedure, combined with the information provided by individual record cards, should lead to a substantial reduction in the amount of absence from work. It must be understood that this investigation was necessarily limited to a consideration of only a few of the many factors that may cause or be associated with absence and sickness. In a complete investigation attention must, of course, also be given to the physical and psychological environment of the workers. In large factories it is advisable to compare the rates for different departments, or groups of workers, since the rate for the total population is often misleading. And home life, nutrition and transport should if possible be studied, since the health of workers is related to their whole background. This account is concerned with what should be regarded as only some of the preliminary stages of a full inquiry. It is given in some detail in the hope that industrial medical officers and personnel managers may find it useful both for its findings and for the description of the methods of analysis employed.

\section{Summary}

The total time lost through absence from work by the women in a factory during the last six months of 1943 was 17.5 per cent. of the number of working days possible. The corresponding figures for married and single women were 24.9 per cent. and 11.3 per cent. respectively. Married women also had a much higher rate of leaving, mainly because of ill-health and domestic difficulties. Approximately two-thirds of the total time lost was due to sickness absence and only a small proportion to absence without permission. Comparatively few women were responsible for a fairly large proportion of the total time lost.

Absence among married women was highest in the lowest age group (under 25) but among single women it tended to increase with age. In all age groups, married women lost more time than single women but the difference decreased as age increased. The rate of discharge of married women decreased up to the age of about 45 and then increased, while that of single women continued to increase in each higher age group.

There was no marked relation between absence from work and length of service. If anything, married women with less than two years of service lost more time than those employed for longer periods but the trend for single women was irregular. The relation between absence from work and length of service was affected by a progressive lowering of the standard of those accepted for employment and by the weeding out of those most prone to absence. The effect of these two factors would account for the comparatively good record of those who entered the factory before the outbreak of war. (Approximately 45 per cent. of these women were still at work at the end of 1943.)

The chief certified causes of sickness absence were colds and influenza, digestive ailments, diseases of the circulatory system, general debility and pregnancy. Absence due to these causes was particularly noticeable among married women under 25 , and in some cases (digestive ailments and pregnancy) up to about 35 . Absence due to diseases of the circulatory system was still more prominent among married women over 45 . The relatively high rate of sickness among young married women still remained when absences due to pregnancy were excluded. Among single women, sickness absence due to colds and influenza and rheumatism increased with age, but diseases of the circulatory group showed the opposite tendency.

Women who left during the period had a much higher rate of absence through sickness, leave and without permission, than those who remained in employment. Thei sickness rate was almost 30 per cent. of the number of days possible, the main causes among married women being digestive ailments and functional nervous disorders (including 'general debility'). Other causes were pregnancy diseases of the circulatory system, colds and influenza, and genito-urinary diseases. Among single women, functional nervous disorders (including ' general debility') were the chief cause of absence and next in importance were diseases of the circulatory system and digestive ailments.

The relation between age and sickness absence in the group of leavers was often different from that of the main group who remained in employment throughout the period. The most noticeable increases in sickness absence among married leavers were in the digestive and pregnancy groups (under 35 ), the functional nervous (including general debility) and circulatory groups $(25-45)$, and the rheumatism group (over 45). Among single women they were in the digestive, rheumatism and circulatory groups (over 35 ).

Comparisons of absence rates in different groups or factories may be misleading unless the proportions and age distributions of married and single women are taken into account.

\section{Acknowledgments}

The author wishes to acknowledge, with grateful thanks, his indebtedness to Dr. E. Lewis-Faning, of the Medica Research Council's Statistical Department, for his help. especially in the preparation of Table 7. 